Article

\title{
Research on a Systematical Design Method for Nearly Zero-Energy Buildings
}

\author{
$\mathrm{Ji} \mathrm{Li}^{1,2}$, Wei $\mathrm{Xu}^{1,2, * \mathbb{D}}$, Ping Cui ${ }^{1, *}$, Biao Qiao ${ }^{2}$, Siyang $\mathrm{Wu}^{3}$ and Chenghua Zhao ${ }^{4}$ \\ 1 School of Thermal Engineering, Shandong Jianzhu University, Jinan 250101, China; ljcabr@126.com \\ 2 Institute of Building Environment and Energy, Chinese Academy of Building Research, Beijing 100013, \\ China; qiaobiao20@163.com \\ 3 Mechanical Engineering School, University of New South Wales, Sydney 2052, Australia; \\ Jasonwucn0320@gmail.com \\ 4 College of Civil Engineering \& Architecture, China Three Gorges University, Yichang 443002, China; \\ chenghua@ctgu.edu.cn \\ * Correspondence: xuwei@cabr.com.cn (W.X.); sdcuiping@sdjzu.edu.cn (P.C.)
}

Received: 25 September 2019; Accepted: 21 November 2019; Published: 9 December 2019

\begin{abstract}
As a result of the impact of energy consumption, research on ultra-low energy, nearly zero-energy, and zero energy buildings has been conducted in China. However, the design of the nearly zero-energy building is flexible; the traditional architectural design method is not fully applicable to nearly zero-energy buildings. The paper proposed a performance-based design method based on overall energy consumption and progress for the nearly zero-energy building. The design process of the relevant cases was also analyzed. The factors of cold and heat sources, environment, and renewable energy were combined to make a comprehensive analysis to get the optimal scheme of the nearly zero-energy building in the case. In general, the performance-based design method has a certain guiding significance for the design of nearly zero-energy buildings and certainly promotes the expansion of the nearly zero-energy building industry in China.
\end{abstract}

Keywords: nearly zero-energy building; traditional design method; performance-based design method; design process

\section{Introduction}

With the development of the social economy, the urbanization process has rapidly advanced, and the living standards for humans have continuously improved. This has resulted in high energy consumption and a large number of pollutant emissions. Energy supplies have become increasingly exhausted, and environmental problems are raising significantly more concern. According to previous statistics, global building energy consumption has reached $25-40 \%$ of the total global energy consumption. In China, the energy consumption of building operations occupies about $20 \%$ of the total energy consumption of the whole country [1]. Building energy conservation has become a global focus that requires further development. At present, there are two main directions for building energy conservation, namely "developing sources" and "reducing consumption". "Developing sources" refers to the development and use of new energy sources, while "reducing consumption" refers to the reduction of building energy consumption through new techniques.

At the 21st UN General Assembly in December 2015, the prediction of the rapid growth of energy consumption in the whole life cycle of buildings in the next 30 years has attracted wide attention from all countries. There is a consensus on the importance of special energy conservation and emission reduction work for buildings. Nearly zero energy consumption buildings show irreplaceable advantages in 
building energy saving, reducing consumption, and improving the efficiency of renewable energy utilization [2].

The construction of nearly zero-energy buildings, which are designed with high-performance building envelopes, high airtightness, efficient energy-consuming equipment, and renewable energy utilization, is an important and efficient approach to reduce the building energy consumption and achieve building energy conservation. The airtightness of the whole building directly affects the energy consumption of the building. Taking Germany as an example, it is required that the ventilation times of ordinary natural ventilation buildings should be less than or equal to $3.0 \mathrm{~h}^{-1}$, mechanical ventilation buildings should be less than or equal to $1.5 \mathrm{~h}^{-1}$, and passive buildings should be less than or equal to $3.0 \mathrm{~h}^{-1}$ [3]. For this reason, Europe, the United States, and other countries have conducted a significant amount of research on nearly zero-energy buildings and have also made energy strategic plans and policy aims [4].

The development and promotion of nearly zero-energy buildings require "political priority". National energy laws and policies are an important way to promote energy efficiency in buildings and to provide direction for the development of the construction industry. According to relevant research, commercial and residential buildings can reduce electricity consumption by $10 \%$ if energy policies are followed [5]. At the same time, a market analysis of qualitative and quantitative indicators has identified the gaps in the carbon target policy, and the social and technical barriers to the implementation of nearly zero energy consumption buildings have been clarified [6].

Unlike traditional architectural design methods that meet standards, the construction of nearly zero-energy buildings involves rebuilding old buildings or designing solutions that are based on climate to ensure comfort. The "combining simulation" method with energy consumption simulation software is used to compare the primary energy demand and emission reduction of different schemes and to improve the feasibility of nearly zero-energy building designs and rebuilding. Firstly, according to previously-verified and widely used technology, different parameters can be changed to give a large number of possible solutions, and the deviations between different solutions can be analyzed to find the energy balance point so that energy-saving properties can be evaluated for different schemes. Secondly, during the process of nearly zero-energy building development, improving the performance of the envelope, the airtightness of buildings, and using high-tech equipment compared to traditional buildings will inevitably lead to increased costs. High airtightness can ensure the thermal insulation performance of building windows. The higher the airtightness level, the smaller the heat loss. Therefore, economical and energy-saving cost-efficiency must be considered when comparing schemes and conducting an energy and cost optimization analysis. In addition, some researchers have suggested that the use of natural lighting, ventilation, and other natural phenomena to improve indoor environment and comfort in nearly zero-energy buildings cannot be ignored; thus, it is necessary to add common benefits to the comprehensive benefit evaluation method for nearly zero-energy buildings [7-11]. Numerous studies have shown that human behavior patterns have a potential impact on the energy required to heat and cool a building. In the design of nearly zero-energy buildings, full consideration of building functions and human behavior patterns can effectively reduce building energy consumption [12,13]. At the same time, the energy consumption monitoring system is configured to not only ensure energy efficiency but also to detect whether the design purpose has been achieved and to convey an awareness of actively reducing energy consumption to the user [14].

Nearly zero-energy building design, construction, and renovation require significant contributions from all parts of the construction industry and are a challenge for the construction industry. A successful nearly zero-energy building requires a reasonable design, new technology, and highly demanding construction [15]. The design of nearly zero-energy buildings needs to take the impacts of different climate zones and energy consumption of different functional buildings into account, and it should also avoid damage to the surrounding ecology [16]. This is usually done using multi-objective optimization algorithms (energy saving, cost, etc.) $[17,18]$. 
Costanzo presents a comprehensive method in view of the problems related to the matching of renewable energy generation and building energy demand. On the demand side, hourly energy profiles are generated using dynamic building simulation, taking into account actual urban morphologies. On the supply side, electricity generated from the system is predicted, considering both the direct and indirect components of solar radiation, as well as local climate variables [19].

Srinivasan et al. proposed a method for assessing the balance of renewable energy use in buildings, using the maximum building renewable energy utilization potential combined with building energy efficiency measures to achieve an optimal nearly zero-energy building design [20].

From the perspective of zero carbon emissions, Whang studied the practical effects of using passive building energy-saving technology (PDE) in residential buildings and analyzed the PDE of existing residential buildings through the analytic hierarchy process to provide some guidance for the selection of optimal architectural designs [21].

Mohamed Hamdy and other studies demonstrated that a nearly zero-energy building design method that only meets the parameters of the envelope structure is not the most economical solution; thus, they proposed a multi-objective optimization method based on the genetic algorithm to minimize carbon dioxide emissions and the initial HVAC system investment. An analysis of the application of this optimization method to three cases showed that the carbon dioxide emissions reduced by $32 \%$, and the initial investment reduction was $26 \%$ [22,23].

Berggren et al. summarized the overall design idea, construction, installation, and energy balance of an office building including parameters, such as reducing building heat loss, improving heat recovery efficiency; using energy-saving equipment to reduce the electricity demand; using passive solar energy and solar-thermal energy, using photovoltaics; and configuring an energy monitoring system to allow users to visualize their energy utilization [23].

Yao et al. used an extensive parametric analysis method of several passive strategies such as building orientation, thermal insulation, glazing area, shading devices, airtightness, and natural ventilation, for a typical apartment block to demonstrate the use of climate-sensitive passive design solutions can help the improvement of indoor thermal conditions while reducing the energy needs and ultimately carbon emissions [24] (see Table 1).

Table 1. Summary of the research results.

\begin{tabular}{|c|c|}
\hline Research Team & Research Contents \\
\hline Costanzo et al. [19] & $\begin{array}{l}\text { the matching problem between renewable energy } \\
\text { generation and building energy demand }\end{array}$ \\
\hline Srinivasan et al. [20] & $\begin{array}{l}\text { a method for assessing the balance of renewable energy use } \\
\text { in buildings }\end{array}$ \\
\hline Whang et al. [21] & $\begin{array}{l}\text { the practical effects of using passive building } \\
\text { energy-saving technology (PDE) in residential buildings }\end{array}$ \\
\hline Hamdy et al. [22] & a nearly zero-energy building design method \\
\hline Berggren et al. [23] & $\begin{array}{l}\text { the overall design idea, construction, installation, and } \\
\text { energy balance of an office building }\end{array}$ \\
\hline Yao et al. [24] & $\begin{array}{l}\text { the effect of passive measures on thermal comfort and } \\
\text { energy conservation }\end{array}$ \\
\hline
\end{tabular}

Compared with foreign countries, research on building energy efficiency developed later in China. In the early stage of development, research, and cooperation in the field of nearly zero-energy consumption technology were mainly carried out abroad. The establishment of several demonstration projects has achieved good energy conservation effects. With the release of relevant energy-saving standards and relevant policies, from 1986 to 2016 , the "30\%-50\%-65\%" three-step energy-saving goal of China's building energy-saving work was basically achieved. The new three-step goal, “30\%-30\%-30\%" for the 2016-2030 period, will be a significant strategy in the development of China's 
energy conservation [25]. Nearly zero energy consumption is an important milestone, and it is the future development direction of China's building energy conservation industry. In the construction of nearly zero-energy consumption system, China has issued technical guidelines for passive ultra-low energy consumption green building and technical standards for nearly zero-energy building. Standards in the field of nearly zero energy consumption have been gradually improved.

At present, the research on the design methods of nearly zero-energy buildings in China is focused on meeting the relevant needs of technology and equipment and following the design pattern that meets certain indicators, so there is a lack of development of systematic design methods aimed at the overall performance of buildings. In order to narrow the gap between nearly zero-energy buildings in China and abroad, this lack of design needs to be addressed. This paper investigates the design requirements and characteristics of nearly zero energy buildings to study and analyze the systematic design method and process of nearly zero-energy building development, which provides some guidance for the promotion and engineering application of nearly zero-energy buildings in China.

\section{Methodology}

In the paper, a performance-based design method based on overall energy consumption and progress for the nearly zero-energy building was proposed. The research process of the paper is as follows. Firstly, the paper introduced the concept of nearly zero-energy buildings and its development and requirements in China. Then, the paper pointed out that passive energy-saving technologies, low-energy systems, and renewable energy are the core components of nearly zero-energy building performance design work and proposed a performance-based design method for the nearly zero-energy building that meets the performance goals and requirements of the owners. Finally, the performance-based design method for the nearly zero-energy building was used in a nearly zero-energy building design case and achieved the design of the nearly zero-energy building.

\section{Nearly-Zero-Energy Buildings}

The definition and performance requirements of ultra-low-energy buildings and zero-energy buildings in different countries are varied due to differences in climate and building use. As a transition to zero-energy buildings, China has proposed the concept of nearly zero-energy buildings.

The concept of nearly zero energy consumption was first proposed by the Chinese government in the 2015 "Passive Ultra Low Energy Building Technology Passive and Ultra low-energy systems Energy Green Building Technology Guidelines" (residential building) [26]. The passive ultra-low energy green buildings defined by the guidelines are actually nearly zero-energy buildings that are characterized by adaptation to climate characteristics and natural conditions through thermal insulation and the airtight performance of the envelope structure using efficient new wind-heat recovery technology to minimize the heating and cooling needs of the building and to make full use of renewable energy to provide a comfortable indoor environment with less energy consumption.

In order to implement the relevant national laws, regulations, guidelines and policies in China, improve the indoor environmental quality and building quality, reduce energy demand, improve energy efficiency, promote renewable energy building applications, and guide buildings to gradually achieve nearly zero energy consumption, the standard "Technical Standards for Nearly Zero Energy Building" [27] has been formulated, which will be released in 2019. The standard can apply to the design, construction, operation, and evaluation of nearly zero-energy buildings. The definition of a "nearly zero-energy building" was revised in the approved "Technical Standards for Nearly Zero-Energy Building" [27]. According to these standards, the buildings should adapt to the climate and natural conditions, the heating and cooling demands should be minimized through passive technical approaches, the efficiency of the energy equipment and system should be maximized, renewable energy sources should be used, the energy system operation should be optimized, a comfortable indoor environment with minimum energy consumption should be provided, and indoor environmental parameters and energy consumption indicators should meet the requirements given by this standard. 
Due to the large land area of China and its five climatic zones [28], the "Technical Standards for Nearly Zero-Energy Building" have different energy consumption indicators for residential buildings in different climatic zones, which indicate the direction for the design of nearly zero-energy buildings in different climatic zones. The standard requires energy savings of more than $75 \%$ for residential buildings and more than $60 \%$ for public buildings in hot and warm summer and cold winter areas. Buildings in severe cold and cold areas no longer require traditional heating methods, and more than $60 \%$ of energy use can be saved in residential buildings. Energy saving in public buildings is over $70 \%$. In addition, the present values of the standard primary energy consumption and renewable energy utilization indicators are also given, as shown in Tables 2 and 3. The related parameters of annual cooling consumption and airtightness of buildings in Tables 2 and 3 are based on the technical standard for nearly zero-energy buildings.

Table 2. Energy consumption indicators of residential buildings with nearly zero-energy consumption in different areas [27].

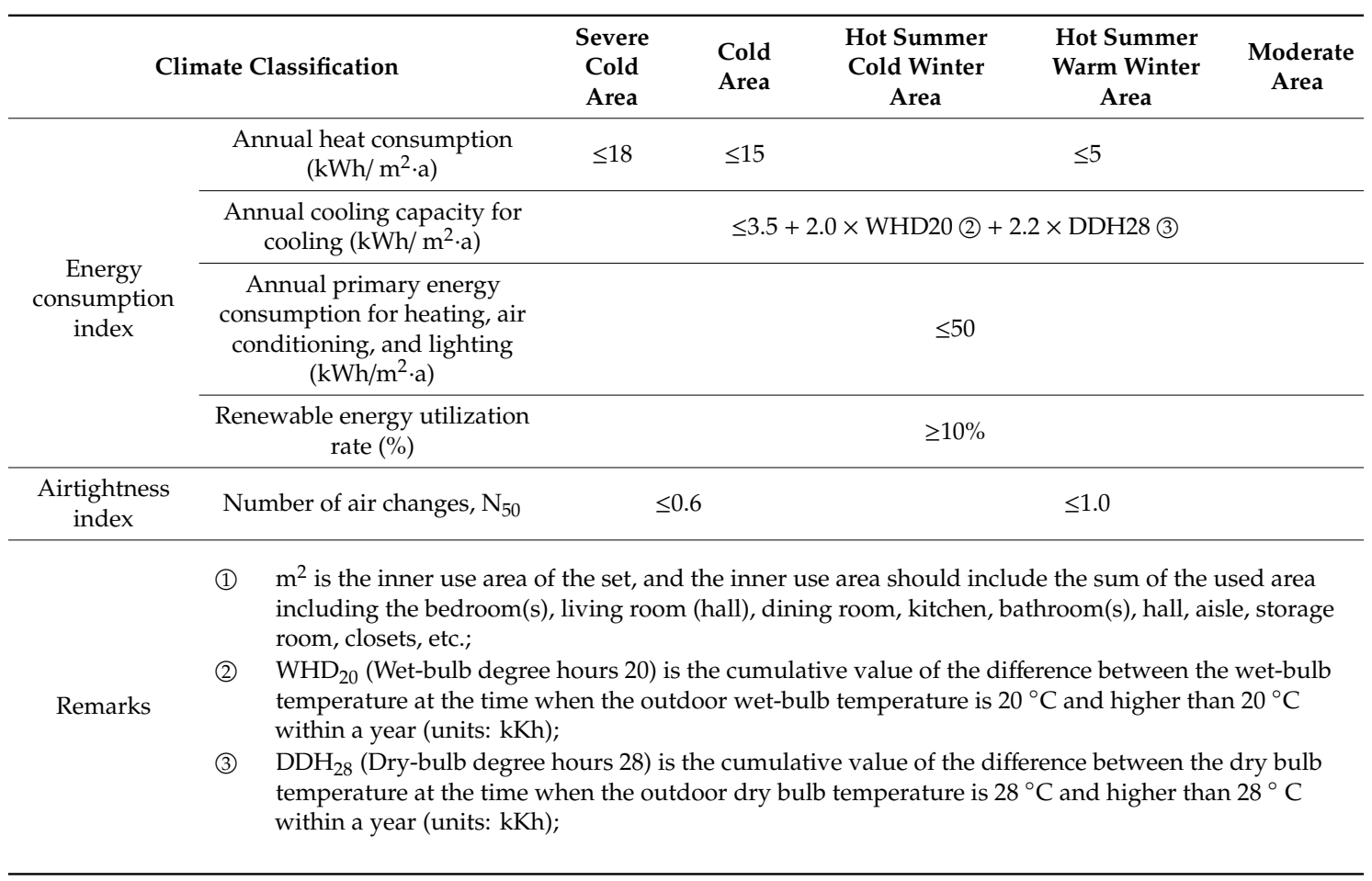

Table 3. Energy consumption indicators of public buildings with nearly zero-energy consumption in different areas [27].

\begin{tabular}{|c|c|c|c|c|c|c|}
\hline \multicolumn{2}{|c|}{ Climate Classification } & $\begin{array}{l}\text { Severe Cold } \\
\text { Area }\end{array}$ & Cold Area & $\begin{array}{c}\text { Hot } \\
\text { Summer } \\
\text { Cold Winter } \\
\text { Area }\end{array}$ & $\begin{array}{c}\text { Hot } \\
\text { Summer } \\
\text { Warm } \\
\text { Winter Area }\end{array}$ & $\begin{array}{c}\text { Moderate } \\
\text { Area }\end{array}$ \\
\hline \multirow{2}{*}{$\begin{array}{l}\text { Performance indicators } \\
\text { of building ontology }\end{array}$} & $\begin{array}{l}\text { Energy-saving rate } \\
\text { of building body }\end{array}$ & \multicolumn{2}{|c|}{$\geq 30 \%$} & \multicolumn{3}{|c|}{$\geq 20 \%$} \\
\hline & $\begin{array}{l}\text { Number of air } \\
\text { changes, } N_{50}\end{array}$ & \multicolumn{2}{|c|}{$\leq 1.0$} & \multicolumn{3}{|c|}{ - } \\
\hline \multicolumn{2}{|c|}{ Renewable energy utilization rate $(\%)$} & \multicolumn{5}{|c|}{$\geq 10 \%$} \\
\hline \multicolumn{2}{|c|}{ Comprehensive energy saving rate of buildings } & \multicolumn{5}{|c|}{$\geq 60 \%$} \\
\hline
\end{tabular}

\section{Systematic Design Method for Nearly Zero-Energy Buildings}

Nearly zero-energy buildings require the design concept of "passive design priority and active optimization" to be applied. Firstly, high-performance building insulation and doors and windows are 
used to reduce the building's own heating and cooling load requirements, and then, efficient energy systems are applied, which prioritize the use of renewable energy to reduce energy consumption from traditional sources. The aim is to achieve the energy-saving goals established in the guidelines. Through multi-parameter and multi-factor simulation analysis, a good energy-saving effect can be obtained.

The nearly zero-energy building concept should be used throughout the whole process (planning, design, construction, operation, etc.). The earlier relevant concepts are used in the implementation of the project, and it is favorable to implement relevant technologies and work. The scheme and design used for nearly zero-energy buildings are the foundations of the project. The systematic design method of nearly zero-energy buildings was proposed based on the required features of these buildings.

\subsection{Applicability Analysis of Traditional Design Methods}

At present, the design method adopted by most buildings in China is regarded as a "prescriptive method" [29]. Based on the provisions of national standards and the industry norms of various professions, there are various design indicators that must be met to ensure that the design meets the requirements of various parameters. This method has certain limitations for the design of nearly zero-energy buildings.

1) The traditional design method selects and designs the envelope structure within the limits of the standard value range. However, nearly zero-energy buildings should not only meet the standards but should also "adapt to local conditions" to achieve energy-saving and cost optimization with the most reasonable design.

2) Traditional design methods were designed by each specialty individually, and there is a lack of balance in the overall performance of the buildings. Compared to traditional architectural design methods, energy-saving goals are often not achieved due to a lack of communication between the various specialties. Nearly zero-energy buildings have an improvement in terms of the overall performance of the building and a reduction in overall energy consumption, which requires coordination and cooperation among various specialties.

3) The design scheme of the traditional design method is not optimized. In the design of nearly zero-energy buildings, many schemes are usually evaluated, and only the most optimized scheme is implemented.

Based on the above analysis, due to the flexibility of the nearly zero-energy building design process, multiple parameters are required. Multi-scheme analysis, the traditional fixed-mode design method, obviously cannot satisfy this demand. The design of nearly zero-energy buildings should fully consider the overall performance goals and energy-saving technology features to achieve energy-saving and economic optimization.

\subsection{Characteristics of Nearly Zero-Energy Building Design Methods}

Nearly zero-energy buildings adopt a variety of energy-saving technologies, so it is necessary to fully assess the effects of different energy-saving technologies and propose an ideal technical solution for nearly zero-energy buildings. Therefore, to make full use of various energy-saving technologies, at the planning and design stages, the comparison and optimization of building energy efficiency programs must be completed to achieve energy efficiency and economic optimization. The nearly zero-energy buildings mainly use the following three technologies, as shown in Figure 1.

1) Passive energy-saving technology: This emphasizes the integration of architecture and aspects of the natural environment, such as temperature and humidity, lighting, wind, and other factors that affect buildings. The main passive energy-saving technologies include natural ventilation, the use of a high-performance envelope, the treatment and avoidance of a thermal bridge, high airtightness, and high-efficiency shading. 
2) Low-energy systems: This mainly refers to reducing the active energy consumption in the building by selecting a high-efficiency equipment system to meet the requirements for building lighting, hot water supply, heating, cooling, ventilation, and so on. The main technologies include efficient and suitable cooling and heating source systems, intelligent lighting and metering control, heat reuse technology, and efficient ventilation systems.

3) Renewable energy utilization: This aims to reduce the primary energy consumption of buildings by actively using renewable energy, for example, through the use of wind power, photovoltaic power, and ground source heat pumps.

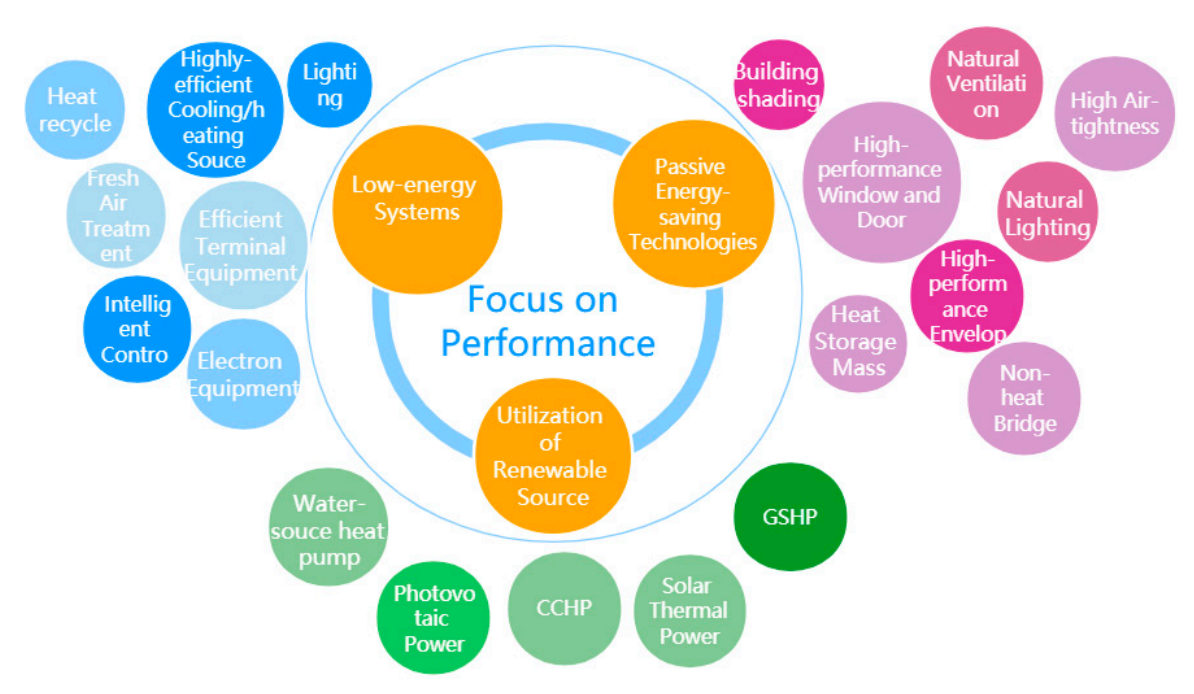

Figure 1. The main energy-saving technologies. Remarks: CCHP_Combined Cooling Heating and Power; GSHP—Ground Source Heat Pump.

Passive energy-saving technologies, low-energy systems, and renewable energy are the core components of nearly zero-energy building performance design work. A large number of possible solutions can be obtained by changing the design parameters, and continuous optimization and adjustment occur to achieve the optimal performance target. However, because many factors affect performance, the parameter changes of each individual energy-saving technology will affect the building energy-saving effect of the entire scheme. At the same time, under the premise of using energy consumption indicators as constraints, building design is also restricted by cost-effectiveness. Therefore, the optimization process of performance-based design is a complex process of continuous optimization.

Hamdy et al. proposed a PR_GA optimization method in 2009 [30]. Firstly, this involves optimizing passive energy-saving technology solutions. Using the idea of the single-variate, under the condition that the other design parameters are constant, every single technical parameter of the passive energy-saving technology is set as a variable, and the points of the building energy consumption that change under the single-variable condition are obtained through a calculation. This determines the influence of energy-saving technology parameters on the building energy of the project and also establishes a standard passive energy-saving technology combination scheme. Secondly, based on the passive energy-saving technology combination scheme obtained in the first stage, different low-energy systems combinations are applied and using the same method, the building energy-saving, and economic calculation results with different scheme combinations are obtained and displayed on a scatter plot. Combined with the simulation, the best (energy-efficient or economically optimal) active energy-saving solution is selected based on the result of the scatter plot. Finally, the project resource conditions and energy consumption simulation method are used to complete the comparison and selection of renewable energy utilization plans until the established energy conservation goals are 
achieved and the complete architectural design plan is developed. Figure 2 is the schematic diagram of a scatter plot optimization.

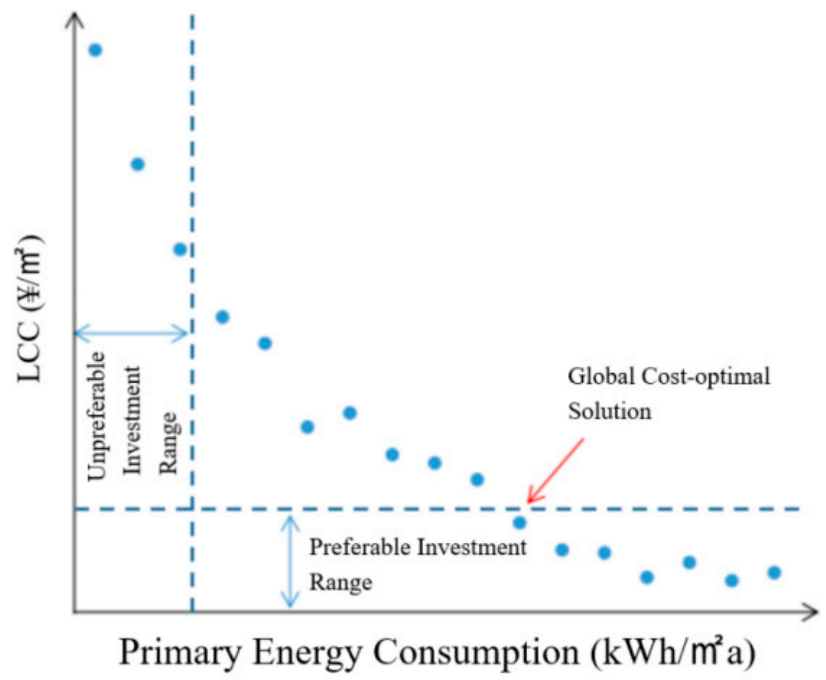

Figure 2. Schematic diagram of a scatter plot optimization.

\subsection{Systematic Nearly Zero-Energy Building Design Method}

In summary, the performance-based design method for nearly zero-energy buildings should use a combination of different energy-saving technologies by utilizing energy-consuming simulation software, weighting various energy-saving technologies, and iteratively optimizing the design scheme to develop a design that meets the performance goals and requirements of the owners. The following principles must be followed in the systematic design of nearly zero-energy buildings:

1) Based on the principle of "passive design priority and active optimization", the building must be adapted to local conditions;

2) Focusing on energy conservation goals, each professional department should cooperate closely with others in the design process. The design process requires each professional department to cooperate closely and to follow the subjective initiatives of the designer.

3) The standardized "prescriptive method" should be abandoned, and continuous iterative optimization should be used.

Therefore, based on the characteristics of nearly zero-energy buildings and design requirements, this paper proposes a systematic design method for nearly zero-energy buildings that considers the overall performance of the building by utilizing an energy consumption simulation and scheme optimization. In the analysis of energy consumption, the factors of cold and heat sources, environment, and renewable energy can be combined to make a comprehensive analysis, so as to get the optimal scheme. The main design flow is shown in Figure 3.

1) Analysis of basic conditions: Fully considering the local climatic conditions of the building, the surrounding environment and the abundance of renewable energy, assess the potential for achieving nearly zero-energy consumption targets and propose preliminary design conditions and design suggestions.

2) Analysis of passive energy-saving technology solutions: Based on the initial architectural design, carry out a dynamic simulation of the building's heating and cooling demands, and, based on the result of the calculation, propose a passive energy-saving technical solution that is applicable to the project to reduce the cooling and heating load demand of the building.

3) Analysis of low-energy systems and renewable energy schemes: Considering the environmental conditions and project requirements, design different HVAC systems and renewable energy 
solutions, simulate and compare energy-saving effects, and obtain a nearly zero-energy building technology solution for the project.

4) Target comparison and selection of the energy-saving effect: Carry out a simulation to determine the energy-saving effect of the nearly zero-energy building technology plan and compare it with the energy-saving goals. If the energy-saving goals are achieved, each professional department can complete design work based on the overall energy-saving technology plan; if the energy-saving requirements are not satisfied, further optimization of the building's energy efficiency technology solutions must be completed, or the proportion of renewable energy utilization must be reduced, until the energy consumption and other indicators are met.

5) Design drawing process: According to the final nearly zero-energy building technology plan, each professional department keeps communicating closely to complete the design of the drawing of the nearly zero-energy building and to provide a plan of the key processing technologies [26].

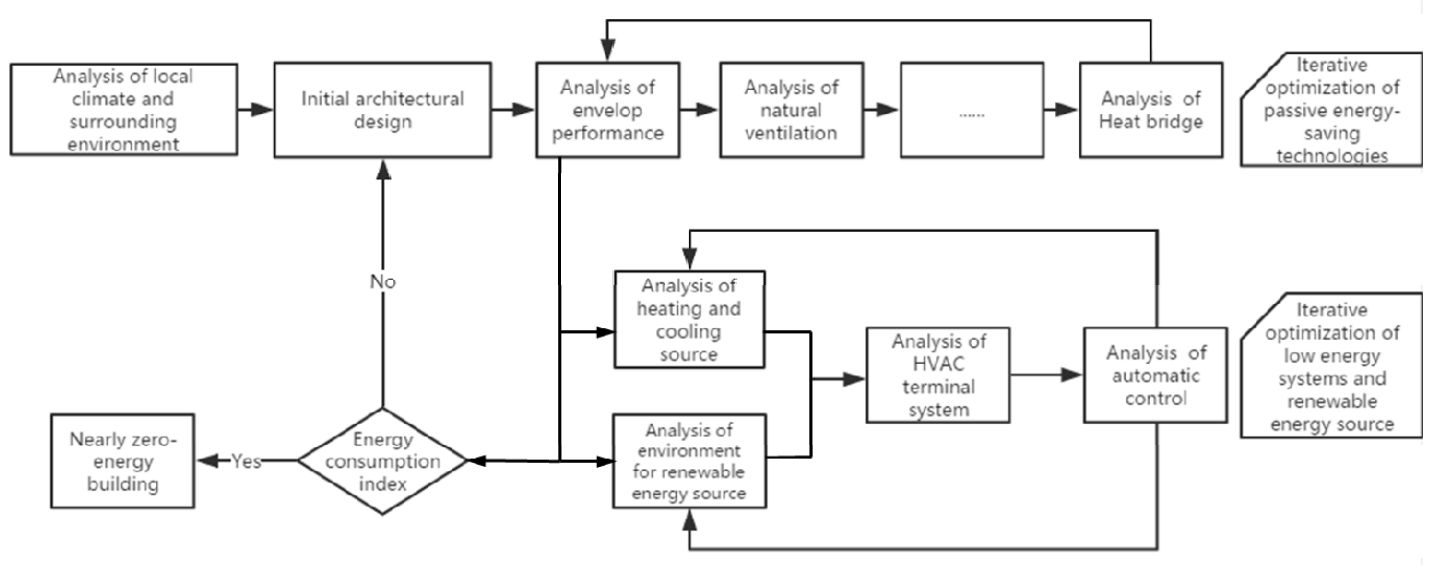

Figure 3. Main design flow chart.

\section{Typical Case Design Method Application}

The nearly zero-energy building design meeting to the energy-saving goal was obtained using the systematic design method mentioned above, including the design and optimization process and continuous parameter optimization.

\subsection{Project Overview}

The first opening area of the first stage of the nearly zero-energy building project of the Innovation Bridge Industrial Park is located in Shijiazhuang City, Hebei Province. This paper introduces the design method of the nearly zero-energy buildings in this area, including a detached building as an example. The main function of the detached building is as an office area. The above-ground floor area of the building is $2029.09 \mathrm{~m}^{2}$, and there are a total of five floors. The shape coefficient is 0.22 . It is intended to be a nearly zero-energy building. The following is an illustration of the initial scheme in Figure 4 . The detached building adopts conventional window-wall structure, and the architectural style is mainly German style.

Combined with the nearly zero-energy building design method proposed in this paper, the design ideas of this project are as follows:

1) Conduct a preliminary energy-saving analysis based on the initial design plans;

2) Use dynamic simulation calculations to analyze the actual energy-saving effects of different energy-saving technologies;

3) Modify the plan according to the calculation results, compare it with the energy-saving targets, and carry out iterative optimization to obtain the optimal building scheme; 
4) After confirming the main building plans, the energy system plan is analyzed to form a nearly zero-energy technical building plan for the project.

5) Complete the design of various professional drawings of the building.

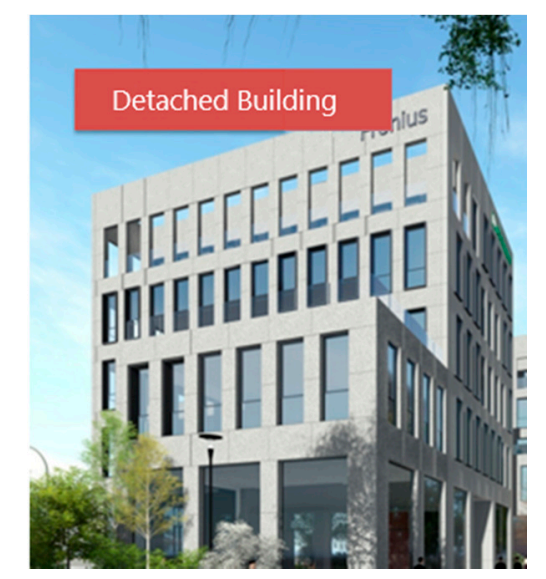

Figure 4. Initial picture of the designed building.

\subsection{Initial Building Plan Optimization}

The initial construction effect of the detached building and the building plan is shown in Figure 5. The figure coefficient of the detached building is 0.22 . The total area of North-South elevation unit is $592 \mathrm{~m}^{2}$, the total area of windows is $279 \mathrm{~m}^{2}$, the ratio of windows to walls is $47 \%$; the total area of East-West elevation unit is $493 \mathrm{~m}^{2}$, the total area of windows is $232 \mathrm{~m}^{2}$, and the ratio of windows to walls is $47 \%$.

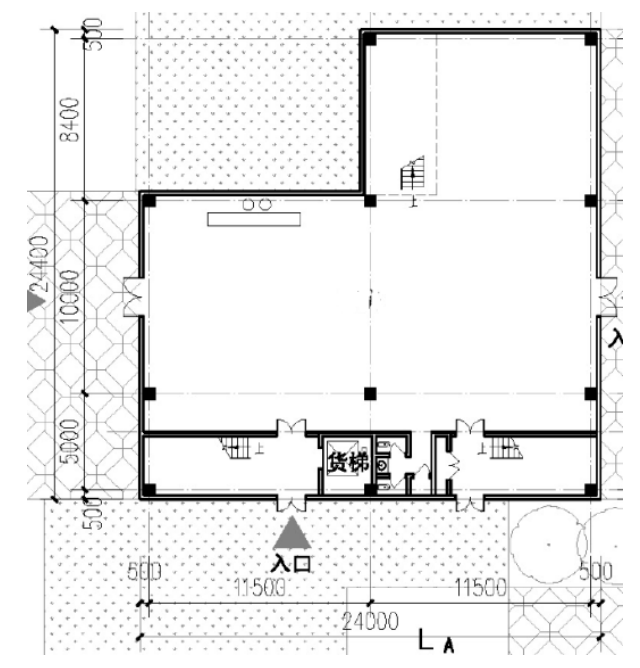

Figure 5. Initial building plane.

Regarding the nearly zero-energy building technology system and engineering, the main problems in the initial building plan are listed below:

1) Glazing ratio and airtightness: The glazing ratio on each face of the detached building is about $47 \%$, and the airtight performance of the building is poor, which will lead to an increase in the cooling load of the building itself;

2) Envelope structure: The insulation performance of the envelope structure does not meet the high-performance requirements of nearly zero-energy buildings. 
3) The initial building plan does not include energy conservation measures such as fresh air heat recycling, natural ventilation, and shading.

In response to the above problems, an energy consumption simulation was used to analyze the changes in heating and cooling requirements of buildings under different energy-saving schemes. As shown in Figure 6, the factors that have the greatest impacts on the building's heating demands are the performance of the building envelope structure, the building glazing ratio, and the exterior window performance. The factors that have the greatest impacts on the building's cooling demands are the building's shading measures and window performance, the glazing ratio, and the building's internal heat.

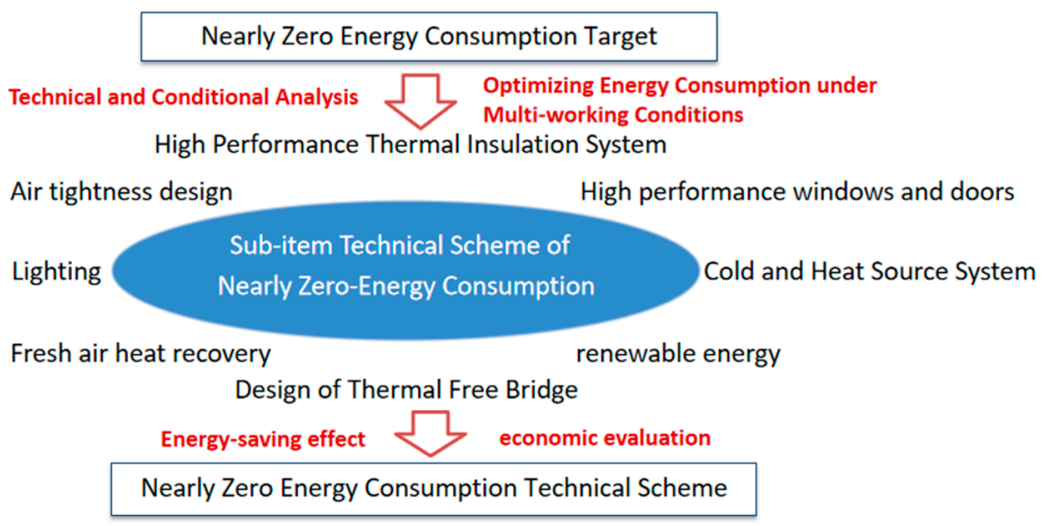

Figure 6. Performance combination diagram.

Scheme 7 adds intelligent lighting to scheme 6; Scheme 6 optimizes the window-wall ratio to scheme 5; Scheme 5 applies high-performance doors and windows to scheme 4 , but does not optimize the window-wall ratio; Scheme 4 optimizes the window-wall ratio to scheme 3; Scheme 3 uses a shading device to scheme 2; Scheme 2 applies a high-performance exterior wall roof to scheme 1.

According to the simulation and comparison results of the different energy-saving schemes for the building's cooling and heat load requirements mentioned above, we proposed the following preliminary modifications to the initial design of the project:

1) Ensure that the heat transfer coefficient of the external wall and roof is $0.1-0.2 \mathrm{~W} /\left(\mathrm{m}^{2} \cdot \mathrm{K}\right)$. In this case, the thickness of the external insulation layer of the building should be $200-300 \mathrm{~mm}$. The building plan should consider the influence of external wall thickening on the shape of the building and the window. Effective building thermal insulation treatment can reduce the phenomenon of thermal bridge.

2) Reduce the glazing ratio of the building. It is suggested that the glazing ratio in the south-facing side should reach $0.4-0.45$, the glazing ratio on the east and west-facing sides should reach $0.35-0.4$, and the glazing ratio on the north-facing side should reach $0.25-0.3$.

3) Use external shading technology, also use high-performance doors and windows.

Changes in the annual heating demand and cooling demand of buildings with different energy-saving schemes are shown in Figures 7-10.

Based on the proposed modifications to the initial construction plan of the project, the design department revised the plan and produced drawings of the detached building. The modified picture is shown in Figure 11. It can be seen that the glazing ratio is significantly reduced. Only the window sleeves are retained at the position of previous window holes on the walls, which contributes to the building's aesthetic sense and gives its shape consistency. At the same time, due to the thick insulation layer of the building, the sunk window is obvious; therefore, the transparent area of the ground floor is significantly reduced. 
Annual Heating Demand in Different Schemes $\left(\mathrm{kWh} / \mathrm{m}^{2} \mathrm{a}\right)$

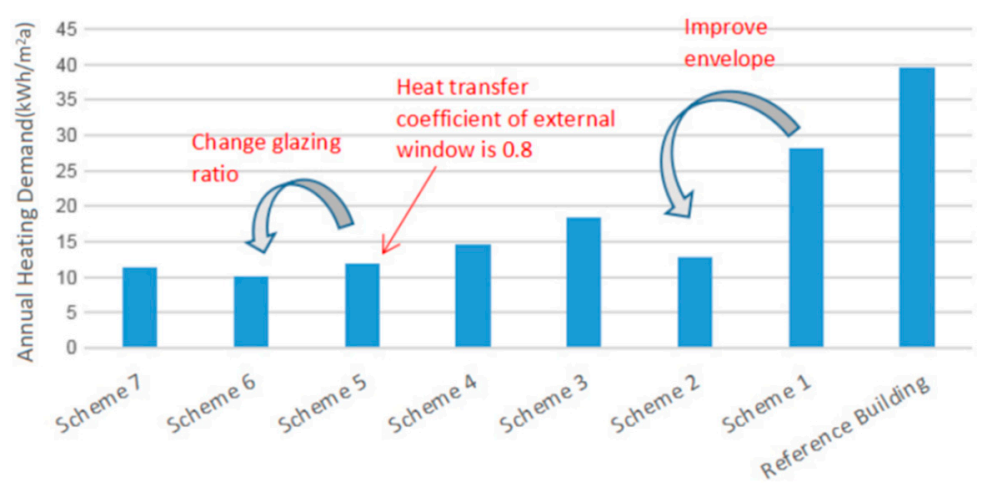

Figure 7. Changes in the annual heating demand of buildings with different energy-saving schemes (detached building).

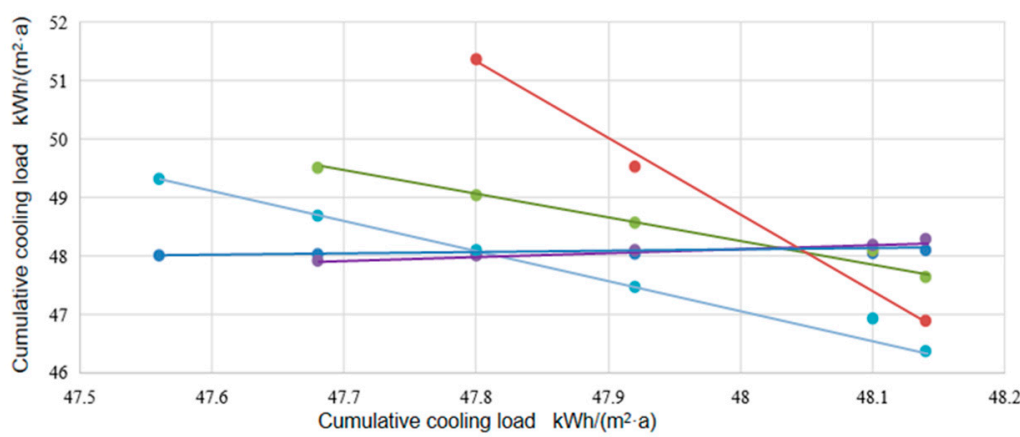

- Adjusting accumulative cooling load of roof $\mathrm{K}$ value $\mathrm{kWh} /\left(\mathrm{m}^{2} \cdot \mathrm{a}\right)$

- Adjusting cumulative cooling load of shading mode $\mathrm{kWh} /\left(\mathrm{m}^{2} \cdot \mathrm{a}\right)$

- Cumulative cooling load under different lighting efficiency $\mathrm{kWh} /\left(\mathrm{m}^{2} \cdot \mathrm{a}\right)$

- Adjusting the accumulative cooling load of the $\mathrm{K}$ value of the outer window $\mathrm{kWh} /\left(\mathrm{m}^{2} \cdot \mathrm{a}\right)$

- Cumulative cooling load with different heat recovery efficiency $\mathrm{kWh} /\left(\mathrm{m}^{2} \cdot \mathrm{a}\right)$

Figure 8. Performance-based analysis of cumulative cooling load effect.

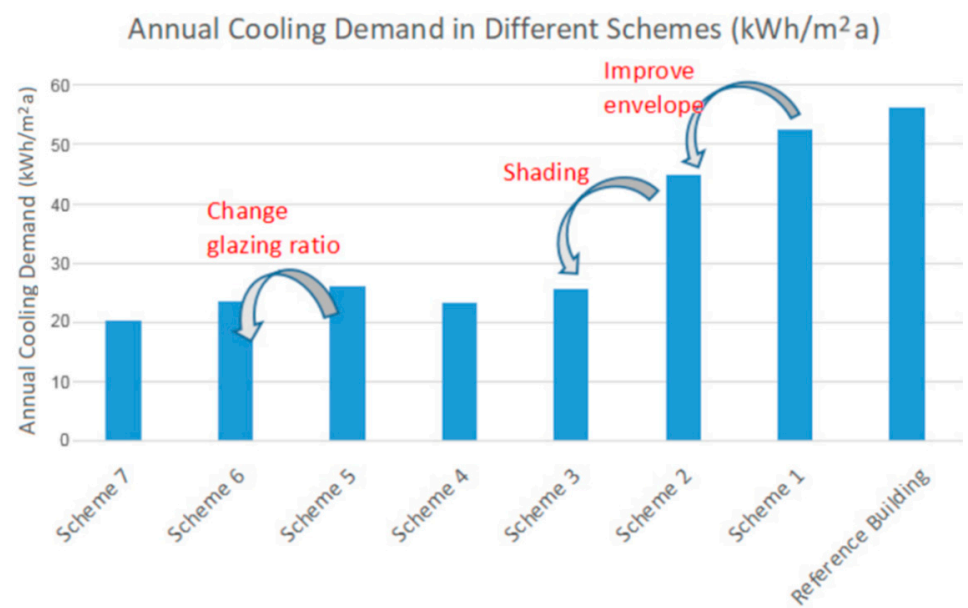

Figure 9. Changes in the annual cooling demand of buildings with different energy-saving schemes (detached building). 


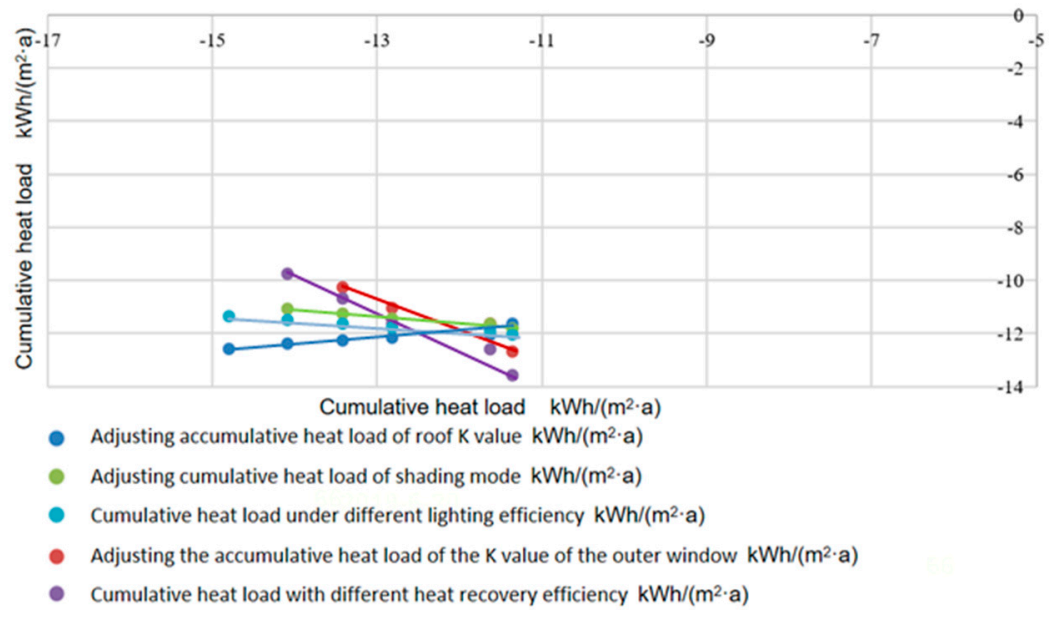

Figure 10. Performance-based analysis of the cumulative heat-load effect.

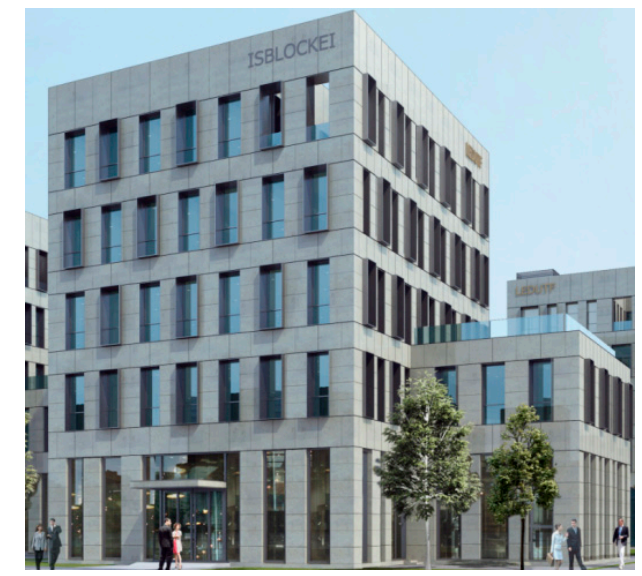

Figure 11. Picture of the detached building's optimization plan.

According to the statistical results of the optimized building drawings, the area ratio of window to wall of the detached building has the most significant change. The area ratio of the window to wall of each orientation is close to 0.5 , which is greatly reduced, and the area ratio of the window to wall of each orientation is within the recommended value range. Among them, the ratio of the east window to wall is 0.34 , the ratio of the west window to wall is 0.34 , the ratio of the north window to wall is 0.15 , and the ratio of the south window to wall is 0.33 .

\subsection{Optimization of Energy Efficiency Technical Solutions}

The system design method of nearly zero-energy buildings needs to compare and optimize the energy-saving effect of different building energy-saving schemes. The calculation and analysis of energy-saving effects of building schemes need to establish a reference building (the standard building set up according to the energy-saving requirements of "Design standard for energy efficiency of public buildings" GB50189-2015) and the designed building (the optimized initial plan) model. The reference building is the basic computational building which was designed according to the index of the envelope structure parameters of the "Design standard for energy efficiency of public buildings" GB50189-2015, and the building structure of the reference building is the same as the designed building. The energy consumption of the designed building under different energy-saving schemes should be compared and analyzed with reference to the energy consumption of the reference building. 
In this paper, IBE-e passive ultra-low energy consumption evaluation tool and building dynamic energy consumption simulation software TRNSYS are combined to compare and analyze the energy-saving effect of different energy-saving schemes based on building energy consumption.

Firstly, for passive energy-saving technical solutions, by using high-performance building envelopes, high-performance windows and doors, high-efficiency external shading, optimized window, and wall area ratio, new wind-heat recovery, and other energy-saving technical practices, different passive energy-saving technical solutions are combined to give different solutions. The dynamic energy consumption of the reference building and buildings under different schemes is calculated. Scheme 1 is a reference building designed according to the index of the envelope structure parameters of the "Design standard for energy efficiency of public buildings" GB50189-2015. Scheme 2 increases the insulation thickness of the building envelope structure, uses high-performance roofing, exterior walls, and exterior windows, reducing the heat transfer coefficient of the building envelope structure and realizing the design of the building without a thermal bridge. The detached building uses an external window with a heat transfer coefficient of $0.8 \mathrm{~W} /\left(\mathrm{m}^{2} \cdot \mathrm{K}\right)$. Scheme 3 adds a fresh air heat recycling system based on scheme 2; the system's heat recycle efficiency is $75 \%$. Scheme 4 adds natural ventilation measures based on scheme 3. Detailed parameter settings of the different Schemes are shown in Table 4 .

Table 4. Detailed parameter settings of different schemes with different passive energy-saving technical solutions.

\begin{tabular}{|c|c|c|c|c|}
\hline Subitem & $\begin{array}{l}\text { Scheme } \\
\text { 1-Reference } \\
\text { Building }\end{array}$ & Scheme 2 & Scheme 3 & Scheme 4 \\
\hline Envelope & Standard & $\begin{array}{l}\text { High-performance } \\
\text { envelope }\end{array}$ & $\begin{array}{l}\text { High-performance } \\
\text { envelope }\end{array}$ & $\begin{array}{l}\text { High-performance } \\
\text { envelope }\end{array}$ \\
\hline $\begin{array}{l}\text { Doors and } \\
\text { windows }\end{array}$ & Standard & $\begin{array}{l}\text { High-performance } \\
\text { windows }\end{array}$ & $\begin{array}{l}\text { High-performance } \\
\text { windows }\end{array}$ & $\begin{array}{l}\text { High-performance } \\
\text { windows }\end{array}$ \\
\hline Shading & No & External Shading & External Shading & External Shading \\
\hline Heat Recycling & No & No & Yes & Yes \\
\hline Natural Ventilation & No & No & No & Yes \\
\hline $\begin{array}{c}\text { East Facing } \\
\text { Glazing Ratio }\end{array}$ & 0.34 & 0.34 & 0.34 & 0.34 \\
\hline $\begin{array}{l}\text { West Facing } \\
\text { Glazing Ratio }\end{array}$ & 0.34 & 0.34 & 0.34 & 0.34 \\
\hline $\begin{array}{l}\text { North Facing } \\
\text { Glazing Ratio }\end{array}$ & 0.15 & 0.15 & 0.15 & 0.15 \\
\hline $\begin{array}{l}\text { South Facing } \\
\text { Glazing Ratio }\end{array}$ & 0.33 & 0.33 & 0.33 & 0.33 \\
\hline $\begin{array}{l}\text { Roof heat transfer } \\
\text { coefficient, } \\
\mathrm{W} /\left(\mathrm{m}^{2} \cdot \mathrm{K}\right)\end{array}$ & 0.45 & 0.135 & 0.135 & 0.135 \\
\hline $\begin{array}{l}\text { External wall heat } \\
\text { transfer coefficient, } \\
\qquad \mathrm{W} /\left(\mathrm{m}^{2} \cdot \mathrm{K}\right)\end{array}$ & 0.5 & 0.185 & 0.185 & 0.185 \\
\hline $\begin{array}{c}\text { External window } \\
\text { heat transfer } \\
\text { coefficient, } \\
\mathrm{W} /\left(\mathrm{m}^{2} \cdot \mathrm{K}\right)\end{array}$ & 2.4 & 0.8 & 0.8 & 0.8 \\
\hline $\begin{array}{l}\text { External window } \\
\text { shading coefficient }\end{array}$ & 0.48 & 0.41 & 0.41 & 0.41 \\
\hline $\begin{array}{c}\text { Heat recycling } \\
\text { efficiency }\end{array}$ & No & No & $75 \%$ & $75 \%$ \\
\hline Shading & No & $\begin{array}{l}\text { Automatic external } \\
\text { shading }\end{array}$ & $\begin{array}{l}\text { Automatic external } \\
\text { shading }\end{array}$ & $\begin{array}{c}\text { Automatic external } \\
\text { shading }\end{array}$ \\
\hline
\end{tabular}


Through the simulation, the building energy consumption of different schemes is obtained, as shown in Table 5 and Figure 12. After calculating and comparing the energy-saving rates of different schemes with that of the reference building, it is found that the energy-saving rate of the detached building reaches $42 \%$ using the high-performance envelope structure, external shading, heat recovery system, and natural ventilation measures. Therefore, the passive energy-saving technical solution of the building does not meet the energy-saving objectives of this project. It still requires the use of cooling and heating sources, energy-saving lighting system technology, and efficient use of renewable energy to reduce primary energy consumption to meet the $60 \%$ energy-saving target of the project.

Table 5. Calculation results of the building's energy consumption with different passive energy-saving technical solutions.

\begin{tabular}{|c|c|c|c|c|}
\hline Subitem & $\begin{array}{l}\text { Scheme } \\
\text { 1-Reference } \\
\text { Building }\end{array}$ & Scheme 2 & Scheme 3 & Scheme 4 \\
\hline $\begin{array}{l}\text { Annual Heating Demand, } \\
\qquad \mathrm{kWh} / \mathrm{m}^{2} \cdot \mathrm{a}\end{array}$ & 39.68 & 17.72 & 7.17 & 7.17 \\
\hline $\begin{array}{l}\text { Annual Cooling Demand, } \\
\mathrm{kWh} / \mathrm{m}^{2} \cdot \mathrm{a}\end{array}$ & 61.57 & 37.1 & 34.16 & 29.66 \\
\hline $\begin{array}{l}\text { Annual Heating Unit } \\
\text { Energy Consumption, } \\
\mathrm{kWh} / \mathrm{m}^{2} \cdot \mathrm{a}\end{array}$ & 45.09 & 20.14 & 8.15 & 8.15 \\
\hline $\begin{array}{l}\text { Annual Cooling Unit } \\
\text { Energy Consumption, } \\
\mathrm{kWh} / \mathrm{m}^{2} \cdot \mathrm{a}\end{array}$ & 12.07 & 7.27 & 6.70 & 5.82 \\
\hline $\begin{array}{l}\text { Annual Transmission and } \\
\text { Distribution System } \\
\text { Electricity consumption, } \\
\mathrm{kWh} / \mathrm{m}^{2} \cdot \mathrm{a}\end{array}$ & 12.92 & 7.84 & 6.57 & 5.43 \\
\hline $\begin{array}{l}\text { Annual Lighting Energy } \\
\text { Consumption } \mathrm{kWh} / \mathrm{m}^{2} \cdot \mathrm{a}\end{array}$ & 21.48 & 21.48 & 21.48 & 21.48 \\
\hline $\begin{array}{l}\text { Annual Equal Primary } \\
\text { Energy Consumption, } \\
\mathrm{kWh} / \mathrm{m}^{2} \cdot \mathrm{a}\end{array}$ & 181.29 & 127.38 & 109.98 & 104.06 \\
\hline Energy Conservation rate & & $29.73 \%$ & $39.33 \%$ & $42.60 \%$ \\
\hline
\end{tabular}

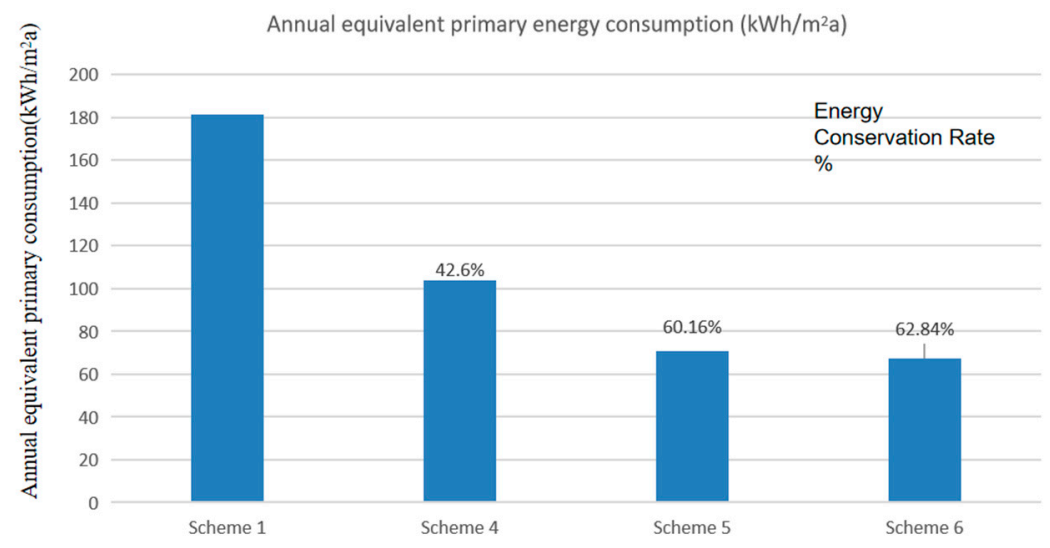

Figure 12. Energy saving rates of the different schemes.

In order to study the technical scheme suitable for this project, firstly, through the analysis of the energy-saving effect of the project design under different low-energy technology schemes, the key 
energy-saving influencing factors are obtained, and the corresponding building scheme suggestions are put forward. Combined with the characteristics of this project, the low-energy technology scheme suitable for this project is put forward, as shown in Table 6.

Table 6. Passive ultra-low energy consumption technology scheme.

\begin{tabular}{cl}
\hline Technical Scheme & \multicolumn{1}{c}{ The Detached Building } \\
\hline Main insulation of exterior wall & $\begin{array}{l}\text { Staggered joint bonding and rivet fixation of 95mm + 95mm thick graphite } \\
\text { polyphenyl board insulation board }\end{array}$ \\
\hline Roof thermal insulation & $220 \mathrm{~mm}$ thick extruded polystyrene board or rigid polyurethane board \\
\hline Ground thermal insulation & $200 \mathrm{~mm}$ thick extruded polystyrene insulation \\
\hline Interior floor thermal insulation & $30 \mathrm{~mm}$ thick graphite polyphenyl board \\
\hline Insulation of partition wall & Staggered seam lapping of $40 \mathrm{~mm}$ thick AEPS thermal insulation board \\
\hline External windows & $\begin{array}{l}\text { The heat transfer coefficient } \mathrm{K} \text { is } 0.8 \mathrm{~W} /\left(\mathrm{m}^{2} \text {.K) for high-performance }\right. \\
\text { aluminum-clad wood windows and 0.41 for SHGC. }\end{array}$ \\
\hline Sunshade & $\begin{array}{l}\text { External adjustable electric shade louvers are installed on the South and } \\
\text { east-west facades of buildings. }\end{array}$ \\
\hline Fresh air heat recovery & $\begin{array}{l}\text { All of them adopt a new air heat recovery system, and the heat recovery } \\
\text { efficiency reaches 75\%. }\end{array}$ \\
\hline Natural draft & $\begin{array}{l}\text { Reducing Air Conditioning Energy Consumption in Transition Season by } \\
\text { Natural Ventilation Technology }\end{array}$ \\
\hline Energy system & Using Ground Source Heat Pump+Water Storage System \\
\hline Terminal system & Radiation terminal system \\
\hline Intelligent lighting & LED lamps + intelligent lighting system, lighting power density up to 4.5W/m2 \\
\hline
\end{tabular}

In summary, for this case, the passive optimized technical solution cannot meet the nearly zero-energy building energy-saving goals. It needs to be combined with an active technical solution. Through software simulation, the final optimization scheme was determined to be scheme 6 , that is, using a high-performance envelope structure, external window and external shading technology, passive technology to reduce the cooling and heating loads of the building, heat recycling, natural ventilation, intelligent lighting, efficient cooling and heating source systems, and a renewable energy source (geothermal energy). It finally achieved a $62.84 \%$ energy saving rate, which meets the energy conservation goal.

\subsection{Discussion}

In the case, using a high-performance envelope structure, external window, and external shading technology, heat recycling, natural ventilation, intelligent lighting, efficient cooling and heating source systems, and a renewable energy source (geothermal energy) achieved the nearly zero-energy design of the building. For other buildings, there are some differences in their characteristics, which lead to differences in the final design schemes. However, the design concept and method are consistent, which is suitable for the design of any nearly zero-energy building.

\section{Conclusions}

This paper analyzed the design requirements and characteristics of nearly zero-energy buildings. Based on the principle of "passive design priority and active optimization, and adapting to local conditions", the paper proposed a performance-based design method for nearly zero-energy buildings. Using the design method in an actual case, the final project energy saving rate was $62.84 \%$ comparing with the reference building and achieved design standards for nearly zero-energy buildings. The research on the systematic design method of nearly zero-energy buildings resulted in the following conclusions: 
1) The traditional "prescriptive method" design model has many limitations. The design of nearly zero-energy buildings should abandon the traditional design mode of buildings, encourage the subjective initiatives of designers, to achieve the optimal design of nearly zero-energy consumption buildings.

2) In the performance-based design method of nearly zero-energy buildings, the core idea is the overall performance of the building. Combining passive energy-saving technologies, low-energy system technologies, renewable energy technologies, and carrying out iterative optimization through a large number of schemes can achieve the goal of improving the energy-saving rate and meet the design standards for nearly zero-energy buildings.

3) For the office building using the performance-based design method, six optimization design schemes were proposed. By comparing the energy-saving effect of different schemes based on building energy consumption, the final optimization scheme was determined to be scheme 6 , using a high-performance envelope structure, external window, and external shading technology, heat recycling, natural ventilation, intelligent lighting, efficient cooling and heating source systems, and a renewable energy source, and achieved a $62.84 \%$ energy saving rate which meets the energy conservation goal of nearly zero-energy buildings.

The development of nearly zero-energy building design methods will certainly promote the expansion of the nearly zero-energy building industry and the realization of China's macro energy-saving goals. At the same time, it will drive the comprehensive development of relevant energy-saving technologies, energy-saving products, and energy-saving policies to comprehensively promote the development of the nearly zero-energy construction industry.

Author Contributions: Conceptualization, J.L. and P.C.; methodology, W.X.; software, B.Q.; validation, C.Z.; formal analysis, W.X.; investigation, B.Q.; resources, S.W.; data curation, J.L.; writing-original draft preparation, P.C.; writing-review and editing, J.L.; visualization, C.Z.; supervision, W.X.; project administration, J.L.; funding acquisition, S.W."

Funding: This research received no external funding.

Acknowledgments: The work described in this paper was supported by Shandong province key research and development project (Project No. 2017GGX40117) and National key research and development project (2016YFC0700803-01).

Conflicts of Interest: The authors declare no conflict of interest.

\section{References}

1. Tsinghua University Building Energy Conservation Research Center. Annual Development Report of Building Energy Conservation in China; Technical Report; Tsinghua university building energy conservation research center: Beijing, China, 2018.

2. United Nations Environment Programme. Sustainable Innovation Forum 2015[EB/OL]; UNEP: Nairobi, Kenya, 2016; pp. 4-7.

3. Zhen, P. Current status of research and Application on integral air tightness of buildings in China. Build. Energy Sav. 2018, 3, 86-89.

4. D' Agostino, D. Assessment of the progress towards the establishment of definitions of Nearly Zero Energy Buildings (nZEBs) in European Member States. J. Build. Eng. 2015, 1, 20-32. [CrossRef]

5. Yu, S.; Tan, Q.; Evans, M.; Kyle, P.; Vu, L.; Patel, P.L. Improving building energy efficiency in India: State-level analysis of building energy efficiency policies. Energy Policy 2017, 110, 331-341. [CrossRef]

6. Attia, S.; Eleftheriou, P.; Xeni, F. Overview and future challenges of nearly zero energy buildings (nZEB) design in Southern Europe. Energy Build. 2017, 155, 439-458. [CrossRef]

7. Ferrari, S.; Beccali, M. Energy-environmental and cost assessment of a set of strategies for retrofitting a public building toward nearly zero-energy building target. Sustain. Cities Soc. 2017, 32, 226-234. [CrossRef]

8. Szalay, Z.; Zöld, A. Definition of nearly zero-energy building requirements based on a large building sample. Energy Policy 2014, 74, 510-521. [CrossRef] 
9. Ferreira, M.; Almeida, M.; Rodrigues, A. Impact of co-benefits on the assessment of energy related building renovation with a nearly-zero energy target. Energy Build. 2017, 152, 587-601. [CrossRef]

10. Semprini, G.; Gulli, R.; Ferrante, A. Deep regeneration vs shallow renovation to achieve nearly Zero Energy in existing buildings: Energy saving and economic impact of design solutions in the housing stock of Bologna. Energy Build. 2017, 156, 327-342. [CrossRef]

11. Ferrara, M.; Fabrizio, E.; Virgone, J. A simulation-based optimization method for cost-optimal analysis of nearly Zero Energy Buildings. Energy Build. 2014, 84, 442-457. [CrossRef]

12. Gaetani, I.; Hoes, P.J.; Hensen, J.L.M. Estimating the influence of occupant behavior on building heating and cooling energy in one simulation run. Appl. Energy 2018, 223, 159-171. [CrossRef]

13. Carpino, C.; Mora, D.; Arcuri, N. Behavioral variables and occupancy patterns in the design and modeling of Nearly Zero Energy Buildings. Build. Simul. 2017, 10, 1-14. [CrossRef]

14. Ascione, F.; Bianco, N.; Böttcher, O. Net zero-energy buildings in Germany: Design, model calibration and lessons learned from a case-study in Berlin. Energy Build. 2016, 133, 688-710. [CrossRef]

15. Hyde, R. From biomimetic design to Nearly Zero Energy Building. Archit. Sci. Rev. 2015, 58, $103-105$. [CrossRef]

16. Charisi, S. The Role of the Building Envelope in Achieving Nearly-zero Energy Buildings (nZEBs). Procedia Environ. Sci. 2017, 38, 115-120. [CrossRef]

17. Pikas, E.; Thalfeldt, M.; Kurnitski, J. Cost optimal and nearly zero energy building solutions for office buildings. Energy Build. 2014, 74, 30-42. [CrossRef]

18. Touloupaki, E.; Theodosiou, T. Energy Performance Optimization as a Generative Design Tool for Nearly Zero Energy Buildings. Procedia Eng. 2017, 180, 1178-1185. [CrossRef]

19. Costanzo, V.; Yao, R.; Essah, E.; Shao, L.; Shahrestani, M.; Oliveira, A.C.; Araz, M.; Hepbasli, A.; Biyik, E. A method of strategic evaluation of energy performance of Building Integrated Photovoltaic in the urban context. Clean. Prod. 2018, 184, 82-91. [CrossRef]

20. Srinivasan, R.S.; Braham, W.W.; Campbell, D.E. Re(De)fining Net Zero Energy: Renewable Energy Balance in environmental building design. Build. Environ. 2012, 47, 300-315. [CrossRef]

21. Whang, S.W.; Kim, S. Determining sustainable design management using passive design elements for a zero emission house during the schematic design. Energy Build. 2014, 77, 304-312. [CrossRef]

22. Hamdy, M.; Hasan, A.; Kai, S. Applying a multi-objective optimization approach for Design of low-emission cost-effective dwellings. Build. Environ. 2011, 46, 109-123. [CrossRef]

23. Berggren, B.; Wall, M.; Flodberg, K. Net ZEB office in Sweden-A case study, testing the Swedish Net ZEB definition. Int. J. Sustain. Built Environ. 2012, 1, 217-226. [CrossRef]

24. Yao, R.; Costanzo, V.; Li, X.; Zhang, Q.; Li, B. The effect of passive measures on thermal comfort and energy conservation. A case study of the Hot Summer and Cold Winter climate in the Yangtze River region. J. Build. Eng. 2018, 15, 298-310. [CrossRef]

25. $\mathrm{Xu}, \mathrm{W}$. Nearly zero energy building research and development in China. Sci. Technol. Rev. 2017, 35, 38-43.

26. Ministry of Housing and Urban-Rural Development of the Peoples Republic of China. Available online: http://www.mohurd.gov.cn/wjfb/201511/t20151113_225589.html (accessed on 10 November 2015).

27. GB/T 51350-2019. Technical Standards for Nearly Zero Energy Building. Available online: http://www.waizi. org.cn/bz/63925.html (accessed on 24 January 2019).

28. Jianchao, L.; Lintao, Z.; Lihua, Z. Discussion on Design Method of Enclosure Structure of Ultra-Low Energy Consumption Residential Buildings in Different Climate Regions. Build. Energy Conserv. 2019, 47, 87-91.

29. Wu, X.T. Consideration of Design Method of Ultra-low Energy Green Building and Case Analysis-Taken Tianjin Zhongxin Eco-city Public House Exhibition Center as the Example. Constr. Technol. 2014, 22, 58-65.

30. Hamdy, M.; Hasan, A.; Siren, K. A multi-stage optimization method for cost-optimal and; nearly-zero-energy building solutions in line with the EPBD-recast 2010. Energy Build. 2013, 56, 189-203. [CrossRef]

(C) 2019 by the authors. Licensee MDPI, Basel, Switzerland. This article is an open access article distributed under the terms and conditions of the Creative Commons Attribution (CC BY) license (http://creativecommons.org/licenses/by/4.0/). 